\title{
POTENSI PEMUKIMAN DI HANDIL SAKA KAWANG, KALIMANTAN TENGAH
}

\author{
Yuka Nurtanti Cahyaningtyas*
}

\author{
Balai Arkeologi Banjarmasin, Jalan Gotong Royong II, RT 03/06, Banjarbaru 70711, Kalimantan Selatan; \\ Telepon (0511) 4781716; Facsimile (0511) 4781716
}

Artikel masuk pada 26 Februari 2012

Artikel selesai disunting pada 23 September 2011

\begin{abstract}
Abstrak. Sejumlah penelitian arkeologis di wilayah administratif Kabupaten Pulang Pisau telah dilakukan selama 1986-1998. Hasil penelitian tersebut menunjukkan pernah ada pemukiman kuna abad ke-14 sampai ke-15 Masehi di kawasan tersebut. Pada survei 2011 di Handil Saka Kawang, pengeboran tanah di kawasan Handil Saka Kawang menghasilkan empat lapisan tanah lempung yang bervariasi antara lain menurut warna, tekstur, struktur, dan permeabilitasnya. Tulisan ini membahas kemungkinan adanya pemukiman kuna berdasarkan data lingkungan dan geologisnya. Kajian tersebut menunjukkan pernah adanya alur sungai purba yang dapat menjadi daya dukung aktivitas dan kelangsungan hidup manusia di kawasan tersebut.
\end{abstract}

Kata kunci: lingkungan, geologi, geomorfologi, lapisan tanah, lapisan budaya, sungai purba, pemukiman

\begin{abstract}
POTENTIAL SETTLEMENTS IN HANDIL SAKA KAWANG, PULANG PISAU DISTRICT. A number of archaeological research had been carried out in the district administrative of Pulang Pisau during 1986-1998. The results showed there were ancient settlements existed during the $14^{\text {th }}-15$ th century in the region. During the 2011 survey in Handil Saka Kawang, the land drilling in Handil Saka Kawang produced four clay layer which varies by the color, texture, structure, and permeability. This paper discusses the possibility of the existence of ancient settlements based on environments and geological data. The study indicates an ancient river channel had existed which may support human activities and survival in that region.
\end{abstract}

Keywords: environment, geology, geomorphology, stratigraphy, cultural layer, ancient rivers, settlement

\section{A. Pendahuluan \\ 1. Latar Belakang}

Handil Saka Kawang merupakan salah satu nama anak Sungai Kahayan yang terletak kurang lebih $5 \mathrm{~km}$ dari kota Pulang Pisau. Kota
Pulang Pisau adalah salah satu kabupaten baru di Kalimantan Tengah. Kabupaten Pulang Pisau ini merupakan pemekaran dari Kabupaten Kapuas. Handil Saka Kawang ini terletak di Kelurahan Kalawa, Kecamatan

* Penulis adalah calon peneliti pada Balai Arkeologi Banjarmasin, email: yuka.nurtanti@gmail.com 
Kahayan Hilir, Kabupaten Pulang Pisau, Kalimantan Tengah (Gambar 1). Secara astronomis Handil Saka Kawang terletak pada $114^{\circ} 13^{\prime} 56,1^{\prime \prime}$ BTdan $2^{\circ} 45^{\prime} 22,1^{\prime \prime}$ LS. Handil Saka Kawang dalam tulisan penulis terdahulu disebutkan sebagai Handil Saka Kamis kemudian diganti menjadi Situs Pulang Pisau oleh Tim Penelitian (1998), akhirnya oleh Sunarningsih (2011) diluruskan kembali menjadi Handil Saka Kawang.

Lokasi situs ini pertama kali dikunjungi oleh M. Kiwok pada tahun 1986 atas laporan Igon M. Galong. Hasil temuan pada kunjungan itu terdiri atas pecahan keramik asing, pecahan gerabah (tembikar), manik-manik, tonggak-tonggak bekas bangunan, dan sisa perahu yang menurut informasi perahu tersebut secara utuh masih terbenam di lumpur. Pada tahun 1996, dilakukan survei eksploratif dipimpin oleh Naniek Harkantiningsih, salah satu lokasinya adalah Handil Saka Kamis. Dalam survei ini didapatkan temuan permukaan dan temuan hasil penggalian liar, antara lain pecahan keramik asing, artefak batu utuh, artefak batu pecahan, pecahan tembikar, dan artefak kayu. Kemudian pada tahun 1998 dilakukan ekskavasi di situs tersebut dipimpin oleh Naniek Harkantiningsih juga. Penyebutan lokasi Handil Saka Kamis oleh Naniek Harkantiningsih kemudian diganti menjadi Situs Pulang Pisau. Penelitian ekskavasi ini membuka empat kotak gali yang kemudian menguraikan stratigrafi lokasi penelitian

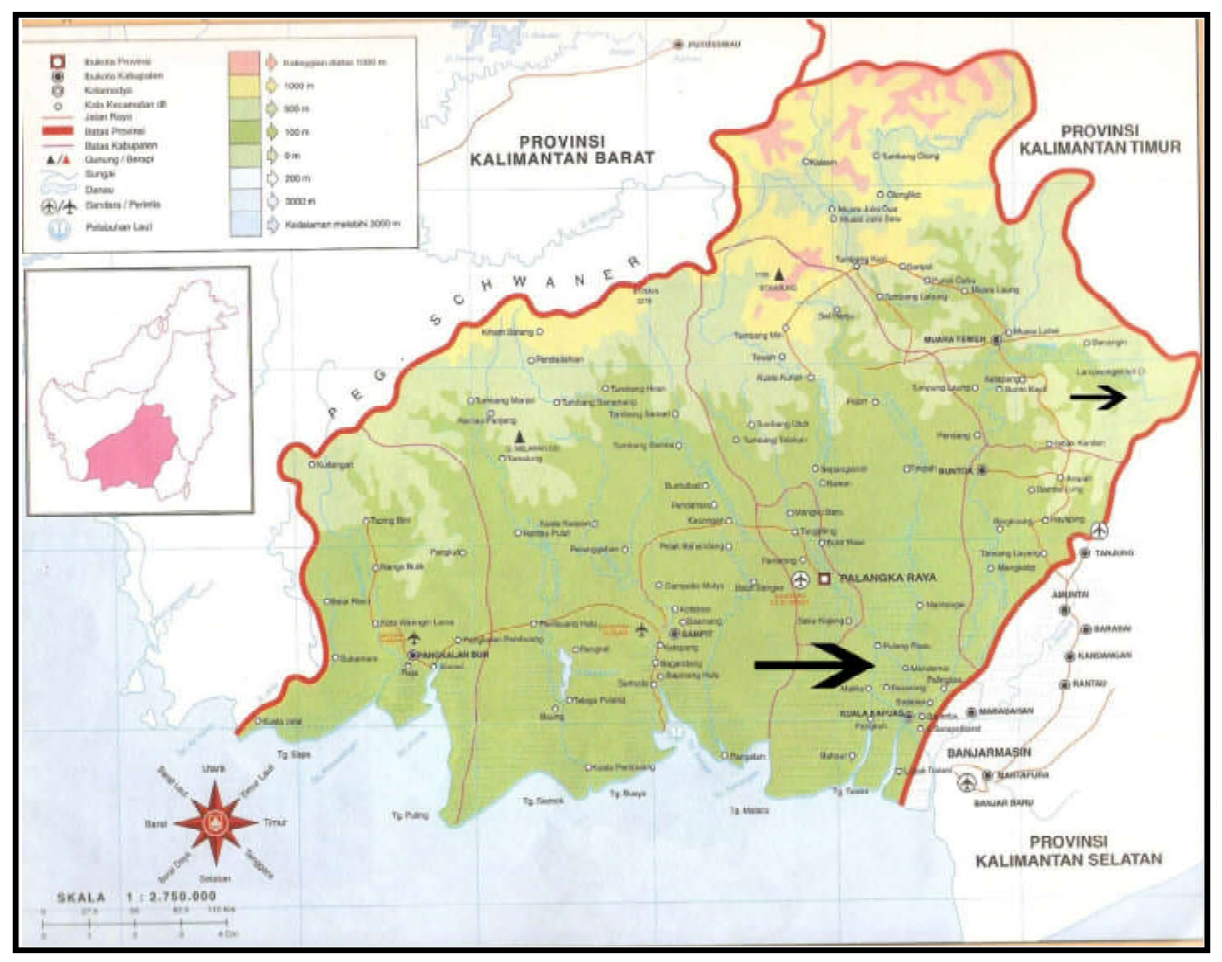

Gambar 1. Lokasi penelitian (tanda panah) 
menjadi tiga lapisan tanah. Lapisan tanah pertama dan lapisan tanah kedua mengandung temuan artefak dan nonartefak. Lapisan tanah yang mengandung temuan itu pada umumnya disebut lapisan budaya. Pada lokasi penelitian ini terdapat dua lapisan budaya. Lapisan budaya pertama berkorelasi dengan temuan yang berasal dari abad ke-14 sampai abad ke-15 Masehi, sehingga kehidupan pada lapisan budaya pertama terjadi semasa dengan umur temuan tersebut. Berdasarkan hukum superposisi maka lapisan budaya kedua yang terletak di bawah lapisan budaya pertama berasal dari masa yang lebih tua dari waktu tersebut.

Pada tahun 2011, dilakukan kembali survei eksploratif di Kabupaten Kapuas dan Pulang Pisau, Provinsi Kalimantan Tengah yang dipimpin oleh Sunarningsih. Salah satu lokasi yang diteliti oleh tim penelitian adalah Handil Saka Kawang. Pada survei eksploratif ini diketahui bahwa tempat yang dimaksud sebagai Situs Handil Saka Kamis berada di Handil Saka Kawang. Lokasi yang bernama Handil Saka Kamis berdasarkan informasi penduduk tidak ditemukan adanya keramik serta penggalian liar dalam rangka pencarian keramik kuna. Jadi penyebutan Situs Handil Saka Kamis yang dimulai pada tahun 1986 ternyata tidak sesuai dengan nama lokasi situs yang sebenarnya dan baru diketahui pada tahun 2011, yaitu terletak di Handil Saka Kawang. Pada penelitian eksplorasi ini dapat dilihat stratigrafi dari tepi sungai Handil Saka Kawang, karena handil tersebut baru saja diperlebar dengan menggunakan alat berat. Stratigrafi Handil Saka Kawang terdiri atas empat lapisan tanah (Gambar 2). Lapisan pertama berukuran lempung lanauan, banyak terdapat rekahan, warna abu-abu muda, terdapat beberapa karbon, banyak terdapat akar. Lapisan kedua berwarna kuning bata,

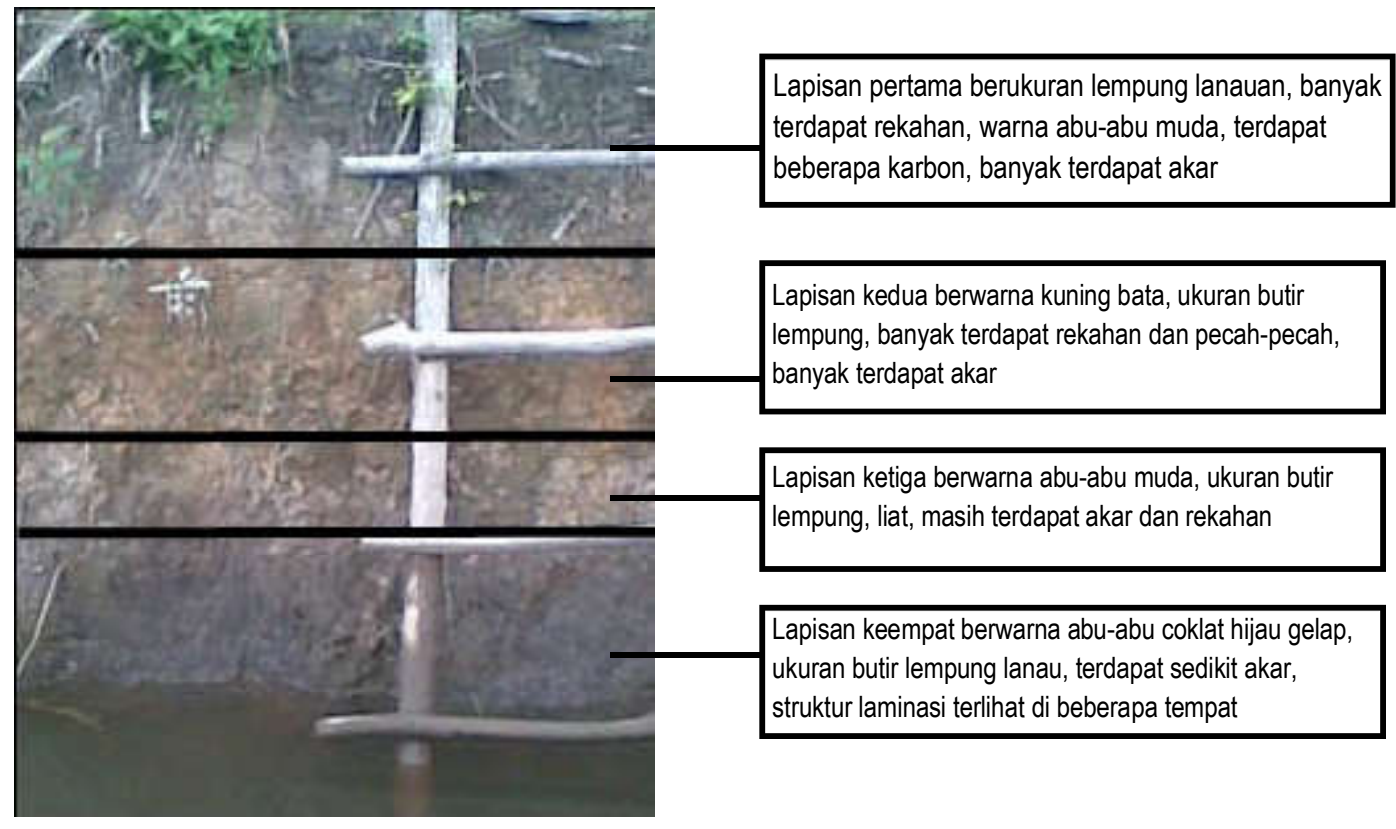


ukuran butir lempung, banyak terdapat rekahan dan pecah-pecah, banyak terdapat akar. Lapisan ketiga berwarna abu-abu muda, ukuran butir lempung, liat, masih terdapat akar dan rekahan. Lapisan keempat berwarna abuabu coklat hijau gelap, ukuran butir lempung lanau, terdapat sedikit akar, struktur laminasi terlihat di beberapa tempat.

Handil Saka Kawang merupakan lokasi yang memiliki temuan yang cukup penting dalam ranah arkeologi Indonesia.Oleh karena itu, perlu diketahui lingkungan pengendapan di lokasi tersebut untuk mendukung data adanya potensi pemukiman. Informasi dasar geologi, khususnya endapan Kuarter secara detail di Kalurahan Kalawa ini belum tersedia. Dengan mempelajari endapan Kuarter tersebut, maka data tersebut dapat dipergunakan untuk mengetahui perkembangan alur sungai purba dan berubahnya lingkungan terutama dataran banjir dan dataran aluvium. Maksud penelitian ini untuk mengetahui potensi pemukiman di Handil Saka Kawang. Tujuan penelitian ini untuk mencari data arkeologi, lingkungan dan geologi yang mendukung potensi pemukiman tersebut.

\section{Metode Penelitian}

Penelitian ini dilakukan dengan menggunakan metode survei, ekskavasi, dan pemboran dangkal. Berikut ini adalah uraian hasil dari ketiga metode tersebut.

\section{a. Survei}

Survei yang dilakukan dalam penelitian ini meliputi survei permukaan dan survei geologi. Adapun hasil yang didapatkan dari survei permukaan berupa temuan pecahan gerabah, pecahan keramik, bagian dari kayu kapal serta bagian dari bekas tonggak pondok.
Hasil dari survei geologi adalah penelusuran alur sungai kuna yang disebut oleh masyarakat setempat sebagai Danau Layang. Penelusuran ini dimulai dari pertemuan Sungai Kahayan dengan sungai kuna di Desa Mentaren di bagian tenggara lokasi penelitian sampai dengan Handil Saka Kamis yang terletak di utara lokasi penelitian.

\section{b. Ekskavasi}

Ekskavasi di Handil Saka Kawang dilaksanakan dengan membuka lima kotak gali. Lima kotak gali ini masing-masing berada di tepian sungai kuna, 3 kotak gali, dan di daerah dengan ketinggian kurang lebih 30 meter dari sungai kuna, yaitu 2 kotak gali. Hasil dari ekskavasi tersebut didapatkan beberapa lapisan, yaitu lapisan pertama, dan lapisan kedua.

Pada lapisan pertama ditemukan artefak berupa pecahan gerabah, pecahan keramik, manik-manik, tanah liat bakar, hematite dan potongan kayu, sedangkan pada lapisan kedua tidak ditemukan artefak.

\section{c. Pemboran Dangkal}

Pemboran dangkal yang dilakukan di Handil Saka Kawang ini meliputi delapan titik. Dari 8 titik tersebut terdistribusi sebagai berikut, 4 titik yang berada di dekat 3 kotak gali sebagai perbandingan lapisan yang terlihat di kotak gali memiliki kesamaan dengan lapisan yang terlihat dari pemboran; 2 titik di dekat lokasi 2 kotak gali yang berada di tepi sungai kuna dan 2 titik berada di tengah sungai kuna.

Secara garis besar ditemukan tiga lapisan pada titik bor yang berada di dekat kotak gali, yaitu lapisan pertama berupa tanah saat ini yaitu pasir lempungan humus hitam; lapisan kedua berupa lempung kuning di beberapa tempat kemerahan; dan lapisan 
ketiga berupa lempung abu-abu. Pada titik bor yang berada di tepi sungai terdapat 2 lapisan, yaitu gambut dan lapisan lempung abu-abu. Adapun titik bor yang terdapat di tengah sungai terdapat 3 lapisan, yaitu gambut, lapisan lempung abu-abu muda dan lapisan lempung abu-abu tua.

\section{B. Geologi Umum}

Geologi umum meliputi stratigrafi serta struktur geologi dan tektonika umum daerah penelitian. Berikut dijelaskan mengenai kedua hal tersebut.

\section{Stratigrafi}

Stratigrafi daerah Pulang Pisau seperti disebutkan dalam Heryanto dan Sanyoto (1994) terdiri atas Batuan Malihan, Granit Belawayan, Batugamping Batununggal, Batuan Gunungapi Haruyan, Formasi Pitap, Formasi Tanjung, Formasi Berai, Formasi Warukin, Anggota Layang Formasi Dahor, Formasi Dahor dan Aluvial. Berikut ini diuraikan stratigrafi daerah Pulang Pisau dari umur tua ke muda.

Batuan Malihan terdiri atas amfibolit dan sekis epidot, sedangkan Granit Belawayan terdiri atas granit, granodiorit serta diorit. Batugamping Batununggal terdiri atas batugamping orbulina dan breksi batugamping yang terendapkan sebagai paparan karbonat. Batuan Gunungapi Haruyan terdiri atas breksi gunungapi dan lava basal, berumur KapurAkhir dan berkedudukan menjemari dengan Formasi Pitap.

Formasi Pitap terdiri atas batulanau kersikan, batupasir kersikan, dan konglomerat aneka bahan, setempat gampingan. Formasi Pitap terendapkan di daerah kipas bawah laut dan berumur Kapur Akhir berdasarkan komponen granit dan batugamping yang dikandungnya. Ketebalan Formasi Pitap ini mencapai $2500 \mathrm{~m}$.

Formasi Tanjung terdiri atas batupasir kuarsa dan batulempung dengan sisipan batubara, setempat bersisipan batugamping, mengandung fosil Palatispira provaleae (setempat bersisipan batugamping, mengandung fosil Palatispira provaleae (Yabe), Discocyclina ompaluabe), Discocyclina ompalus (Fritsch) yang menunjukkan umur $\mathrm{g}$, yaitu petunjuk umur Eosen), terendapkan dalam lingkungan fluviatil sampai dengan laut dangkal. Ketebalan formasi ini mencapai $750 \mathrm{~m}$.

Formasi Berai tersusun atas batupasir mengandung fosil foraminifera besar seperti Spiroclypeus orbitodeus, Spiroclypeus sp. dan lain-lain yang menunjukkan umur Oligosen Miosen Awal dan bersisipan napal. Formasi ini terendapkan dalam lingkungan neritik dengan ketebalan mencapai $100 \mathrm{~m}$.

Formasi Warukin terdiri atas batupasir kuarsa dan batulempung dengan sisipan batubara. Formasi ini terendapkan dalam lingkungan fluviatil dengan ketebalan sekitar $400 \mathrm{~m}$ serta memiliki umur Miosen Tengah sampai dengan Miosen Akhir.

Formasi Dahor tersusun atas batupasir kuarsa lepas berbutir sedang terpilah buruk, konglomerat lepas dengan komponen kuarsa berdiameter $1-3 \mathrm{~cm}$, batulempung lunak, setempat dijumpai lignit dan limonit. Formasi ini terendapkan dalam lingkungan fluviatil dengan tebal sekitar $250 \mathrm{~m}$ dan berumur Plio - Plistosen. Formasi Dahor ini memiliki Anggota Layang yang tersusun atas konglomerat aneka bahan berkomponen semua batuan lebih tua dengan ukuran kerakal - bongkah.

Lapisan termuda adalah aluvial yang tersusun atas lempung kaolinit dan lanau 
bersisipan pasir, gambut, kerakal dan bongkahan lepas. Aluvial ini terendapkan di sungai dan rawa.

\section{Struktur Tektonik}

Dalam Heryanto dan Sanyoto (1994) disebutkan bahwa struktur geologi di daerah ini terdiri atas kelurusan, lipatan, dan sesar yang berarah timur laut - barat daya. Jenis sesar belum dapat ditentukan, namun diduga berupa sesar geser dan sesar normal. Kegiatan tektonik yang baru diketahui dengan jelas adalah pada pasca Miosen, namun diduga kegiatan tersebut sudah berlangsung sebelum Tersier.

Batuan tertua berupa batuan malihan yang diterobos oleh batuan granit (Granit Belawayan) berhubungan dengan proses penelusupan dan berumur Kapur Awal. Pada waktu yang hampir bersamaan terendapkan batugamping orbitulina (Batununggal) yang merupakan endapan paparan karbonat. Batuan-batuan tersebut merupakan alas dari sedimen laut (Formasi Pitap) yang berumur Kapur Akhir pada cekungan muka. Kegiatan gunungapi (Batuan Gunungapi Haruyan) berlangsung sampai dengan Kapur Akhir dan berkedudukan menjemari dengan sedimen lautnya (Formasi Pitap). Pada awal Tersier kemungkinan terjadi benturan yang menimbulkan terendapkannya batuan sedimen dan karbonat sebagai endapan tanah muka. Kegiatan magma pada Tersier diduga merupakan kegiatan pasca penelusupan.

\section{Pemukiman}

Dalam kehidupan sehari-hari, manusia memilih bentuk lahan yang sesuai dengan seleranya. Dalam menentukan pilihan lokasi tempat mereka hidup, telah dipertimbangkan beberapa hal yang dapat mendukung kehidupan mereka. Usaha manusia dalam mengatur dirinya dalam suatu bentang alam ini disebut pola pemukiman (Willey, 1953 dalam Nitihaminoto dan Sulistyanto, 1998).

Dalam konsep masyarakat pada umumnya, lokasi pemukiman dipilih dekat dengan pantai atau sungai karena pantai atau sungai merupakan jalur lalu lintas masa lampau untuk memudahkan segala macam aktivitas sekaligus sumber penghidupan. Selain itu, situs pemukiman ditandai oleh berbagai temuan yang memperlihatkan adanya penggunaan bermacam-macam peralatan antara lain artefak batu, kayu, logam, keramik, tembikar dan kaca (Wibisono dan Kusmartono, 1996).

\section{Pembahasan}

Gambaran umum daerah penelitian ini meliputi fisiografi dan stratigrafi di daerah sekitar Handil Saka Kawang. Lokasi penelitian atau lokasi situs terletak di tepi Sungai Kahayan kurang lebih $5 \mathrm{~km}$ ke arah barat dari kota Pulang Pisau, Kalimantan Barat. Lokasi ini berjarak kurang lebih $3 \mathrm{~km}$ dari bagian barat tepian Sungai Kahayan dan di lokasi ini terdapat tiga macam bentang alam atau bentuk lahan, yaitu:

Fisiografi wilayah penelitian dicirikan oleh dataran rendah yang merupakan tinggian, dataran banjir yang berasal dari bentukan asal fluvial dan aliran sungai kuna. Berdasarkan hasil pemboran dangkal dan ekskavasi, stratigrafi Handil Saka Kamis memiliki tiga lapisan di daerah dataran rendah, dua lapisan di dataran banjir dan tiga lapisan di badan sungai kuna. 
Lapisan di dataran rendah berupa endapan pasir lempungan humus hitam, merupakan lapisan endapan pertama yang berada di atas. Endapan tersebut berupa tanah yang berwarna hitam, berukuran pasir sedang, sedikit pasir halus bercampur dengan lempung dengan sortasi sedang dan endapan bersifat lepas-lepas, tidak menyatu. Lapisan kedua berupa lempung kuning dengan deskripsi sebagai berikut berukuran lempung berwarna kuning di beberapa tempat kemerahan dengan sortasi bagus dan endapan bersifat liat. Lapisan ketiga berupa lempung abu-abu, berukuran lempung berwarna abu-abu dengan sortasi bagus dan endapan bersifat tidak terlalu liat.

Lapisan di dataran banjir berupa endapan gambut coklat kehitaman, merupakan lapisan endapan pertama yang berada di atas. Lapisan tersebut berupa: endapan berupa tanah gambut yang berwarna hitam, banyak terdapat akar-akar gambut dan endapan bersifat lepas-lepas, tidak menyatu. Lapisan kedua berupa lempung abu-abu, berukuran lempung berwarna abu-abu dengan sortasi bagus dan endapan bersifat tidak terlalu liat.

Lapisan di badan sungai kuna sebagai berupa gambut coklat kehitaman, merupakan lapisan endapan pertama yang berada di atas. Lapisan tersebut berupa tanah gambut yang berwarna hitam, banyak terdapat akar-akar gambut dan endapan bersifat lepas-lepas, tidak menyatu. Lapisan kedua berupa lempung abu-abu, berukuran lempung berwarna abu-abu dengan sortasi bagus dan endapan bersifat tidak terlalu liat. Lapisan ketiga berupa lempung abu-abu gelap, berukuran lempung berwarna abu-abu dengan sortasi bagus dan endapan bersifat tidak terlalu liat. Dari hasil deskripsi tersebut, kemungkinan merupakan lingkungan rawa yang dipengaruhi oleh pasang surutnya air Sungai Kahayan.

Berdasarkan hasil survei, temuan artefaktual maupun pemboran dangkal, maka dapat diungkapkan bahwa Handil Saka Kawang memiliki potensi sebagai pemukiman. Pertimbangan yang dijadikan dasar pemilihan lokasi pemukiman adalah dekatnya lokasi dengan sungai atau handil sebagai sumber kehidupan. Manusia menyesuaikan tindakannya dengan alam yang dihuninya. Tindakan manusia dalam mensiasati lingkungan itu dapat dilihat dari sebaran temuan baik terdapat di permukaan maupun temuan yang terdapat di dalam tanah.

\section{Kesimpulan}

Kesimpulan yang didapatkan dari data yang sudah diuraikan di atas antara lain :

1. Berdasarkan hasil ekskavasi di Handil Saka Kawang terdapat dua lapisan endapan, yaitu pasir lempungan humus hitam dan lempung kuning. Artefak hanya terdapat pada lapisan pertama, sedangkan pada lapisan kedua tidak terdapat artefak

2. Berdasarkan hasil pemboran dangkal terdapat beberapa lapisan yang berbeda pada bentuk lahan/ morfologi yang berbeda.

3. Berdasarkan temuan permukaan, hasil ekskavasi, survei geologi, maupun pemboran dangkal disimpulkan bahwa Handil Saka Kawang memiliki potensi sebagai lokasi pemukiman. 


\section{Referensi}

Heryanto, R dan Sanyoto P. 1994. Peta geologi lembar Amuntai, Kalimantan skala 250.000, Bandung, Pusat Penelitian dan Pengembangan Geologi.

Nitihaminoto, Gunadi dan Bambang Sulistyanto. 1998. Permukiman Situs Pulang Pisau, Kabupaten Kapuas, Kalimantan Tengah, Berita Penelitian Arkeologi. Banjarbaru: Balai Arkeologi Banjarmasin.

Poesponegoro, M. D. dan Nugroho Notosusanto. 1993. Sejarah Nasional Indonesia I, Jakarta : Balai Pustaka.

Tim Penelitian. 1998. Penelitian permukiman kuna Situs Pulang Pisau, di Kahayan Hilir, Kapuas, Kalimantan Tengah (Tahap I),
Laporan Penelitian Arkeologi Banjarmasin. Banjarbaru: Balai Arkeologi Banjarmasin. Tidak diterbitkan.

Wibisono, Naniek Harkantiningsih dan Vida Pervaya Rusianti Kusmartono. 1996. Survei eksploratif arkeologi di Provinsi Kalimantan Tengah. Laporan Penelitian Arkeologi Banjarmasin. Banjarbaru: Balai Arkeologi Banjarmasin. Tidak diterbitkan. Sunarningsih. 2011. Penelitian eksploratif arkeologi di Kabupaten Kapuas dan Pulang Pisau, Provinsi Kalimantan Tengah. Laporan Penelitian Arkeologi Banjarmasin. Banjarbaru: Balai Arkeologi Banjarmasin. Tidak diterbitkan. 